\title{
GEOLOGY AND EXPLORATION OF THE BRAÚNA DIAMONDIFEROUS KIMBERLITES, SERRINHA BLOCK, BAHIA, BRAZIL
}

\section{JOSÉ RICARDO THIBES PISANI ${ }^{1}$, KENNETH MELBOURNE TAINTON ${ }^{1}$, ANDREW FERGUSON ALLAN ${ }^{1}$, SÉRGIO BRANDÃO SILVA ${ }^{1} \&$ JEFERSON VARGAS DE MIRANDA ${ }^{1}$}

\begin{abstract}
Systematic prospecting work (alluvial, loam sampling and ground magnetics) in the 1980's and 90's triggered the discovery of the Brauna kimberlitic province in 1992. The province consists of 15 pipes and dykes. The heavy mineral suite for all kimberlites from this province comprises garnets, spinels, clinopyroxenes and rare ilmenites. The chemistry of garnets recovered from the Braúna kimberlites shows the presence of Iherzolitic, eclogitic and harzburgitic garnets. The Brauna province has a Neoproterozoic age $(682 \pm 20 \mathrm{M} . \mathrm{a}$. Rb/Sr in phlogopite) and is intruded into the Nordestina Granodioritic Pluton, within the Serrinha Nucleus.
\end{abstract}

Keywords: Braúna Province, Kimberlites, Serrinha Nucleus, Nordestina Granodioritic Pluton

\begin{abstract}
INTRODUCTION The Braúna Kimberlitic Province is located to the south of Nordestina town in Bahia state, in the Rio Itapicuru basin. The Itapicuru River in Braúna Province was a production center of gold and diamonds in the middle of the $20^{\text {th }}$ century. De Beers Brasil commenced prospecting activities in this area in 1980, based on the historical diamond production and an analysis of the tectonic setting of the area. This activity culminated in the discovery of the Brauna Province, which consists of a group of 15 bodies (blows and dykes) with an approximate trend of N30W. The largest intrusion within this province is the Braúna 3 pipe, located on the margin of the Riacho Grande Creek. The body has a surface area of approximately 1,5 hectares.
\end{abstract}

\section{GEOLOGY, PETROGRAPHY AND AGE}

The

kimberlites in this study intrud into the Nordestina Granodioritic Pluton. This pluton is considered a syntectonic granite emplaced during the Trans-Amazonian orogeny and has been dated at $2.07 \mathrm{Ga}$ (U-Pb in zircon, Rios et al. 2000).

The emplacement of the Braúna 3 kimberlite has been dated radiometrically at $682 \pm 20 \mathrm{Ma}(\mathrm{Rb} / \mathrm{Sr}$ in phlogopite). The rock is petrographically classified as a macrocrystic diopside- and phlogopite-bearing kimberlite of the hypabyssal facies.

The indicator mineral assembly found in this province comprises garnet, chrome-spinel, clinopyroxene and rare ilmenite. Eclogitic and peridotitic garnets are present, with the latter including lherzolitic (G9) garnets with variable $\mathrm{TiO}_{2}$ contents, and lesser harzburgitic (G10) grains. The spinel population includes common grains of diamond-inclusion chemistry.

Garnet thermobarometry (using the Ni-in-garnet method of Ryan et al. 1996) indicates that the geotherm at the time of kimberlite emplacement was typically cratonic $\left(40 \mathrm{~mW} / \mathrm{m}^{2}\right)$.

ASPECTS OF EXPLORATION The initial phase of prospecting in the area by De Beers Brasil, which took place in 1980, was restricted to a stream sampling program of low density and low volume. This programme returned negative results.

In 1989 and 1990 increasing sampling density produced an anomaly comprising garnets and chrome-spinels, located in the Riacho Grande Creek in the Itapicuru River basin.

Follow-up, including systematic stream and soil sampling, led to the discovery of Braúna 1 and Braúna 2 (kimberlite dykes) and Braúna 3 (kimberlite blow), all of which contained mineral chemistry characteristic of diamondiferous kimberlites. This association was confirmed through microdiamond analysis.

Detailed soil sampling and ground-magnetic surveys were carried out over the discovery area, with only the soil sampling campaign defining a further 12 dykes in the region.

This was complemented by a regional Magnetic Airborne Survey, covering an area of $7,600 \mathrm{~km}^{2}$ (line spacing $=250$ meters). No further kimberlites were discovered from follow-up of this survey.

Acknowledgements To the reviewers of RGB for suggestions to the manuscript. 


\section{Referências}

Rios D.C., Davis D.W., Conceição H., Macambira M.J.B., Peixoto A.A., Cruz Filho B.E.da, OliveiraL.L. 2000. Ages of Granites of the Serrinha Nucleus, Bahia (Brazil) An Overview. Rev. Bras. Geoc., 30:74-77.

Ryan C.G., Griffin, W.L., Pearson, N.J. 1996. Garnet geotherms: Pressuretemperature data from Cr-pyrope xenocrysts in volcanic rocks. J. Geophys. Res., 101:5611-5625.

Manuscrito NB-40 Revisão dos autores em 18 de dezembro de 2001 Revisão accita em 19 de dezembro de 2001 